\title{
Arbor
}

\section{Cultura científica, cultura visual. Prácticas de representación en el origen de la ciencia moderna}

Jesús Vega Encabo ${ }^{1}$

Arbor CLXXIII, 683-684 (Noviembre-Diciembre 2002), 521-552 pp.

\section{Introducción}

Las divisiones y escisiones en la cultura, o incluso entre culturas, no son necesariamente arbitrarias o resultado de prejuiciados procesos. Ciertas separaciones están racionalmente motivadas, al menos intraculturalmente. ¿Podría estar justificado el denominado enfrentamiento entre las «dos culturas», la cultura científico-técnica y la cultura humanista? Un modo de comprender la escisión pasaría por detectar los patrones y la dinámica propios de las prácticas en cada una de ellas. Nada más obvio, entonces. ¿Qué podría haber en común entre las prácticas literarias y artísticas, y las intervenciones científicas y tecnológicas sobre la naturaleza? Pero responder a esta pregunta no haría de la escisión una ruptura racionalmente motivada. Argumentar a su favor requiere especificar los intereses, los objetivos o los valores que gobiernan sus respectivas dinámicas internas. En este punto, las matizaciones se imponen: en primer lugar, esto obligaría a nuevas subdivisiones en el interior de cada una de las culturas; en segundo lugar, es fácil comprobar cómo algunos de los valores actúan transversalmente y se filtran entre ellas. Por un lado, ¿qué nos asegura que la ciencia y la tecnología comparten un mismo interés? Por otro lado, ¿no podría decirse que «no sólo la ciencia sino también el arte nos muestra que la realidad, en principio incomprensible, se revela a sí misma gradualmente a través de las relaciones mutuas inherentes en las cosas", como bien sugería Mondrian? O, en otras palabras, ¿no intentan tanto 
científicos como artistas leer el libro de la naturaleza? Si es así, esto nos retrotrae a la pregunta inicial sobre la diferencia en sus prácticas y la justificación racional de la escisión.

Pero quizá no sea este el debate. De hecho, no lo es. La escisión entre las dos culturas no es sino el reflejo de una división fundamental en el terreno del ser, entre la Naturaleza y el Hombre, o en términos kantianos entre la esfera de la Necesidad y de la Libertad. La primera incluiría aquellos aspectos del animal humano que lo conciben en cuanto sometido a las leyes de la naturaleza, a la imbricación causal de los fenómenos. La segunda se expresa en la actividad creadora y constructiva del ser humano. El debate surgido en torno a la escisión de la cultura científico-técnica y la cultura humanista procede de los intentos colonizadores de una sobre la otra ${ }^{2}$. El ciencismo pretende que la imagen del hombre a la cual accede a través de sus métodos empíricos revela la esencia de su naturaleza. El humanismo extrae de la ciencia y de la tecnología su más íntimas motivaciones humanas, ansía reconducirlas a la esencia de la Libertad y Creatividad. Tanto uno como otro asumen ya que no debería existir conflicto entre las posibles imágenes del hombre, entre lo que Sellars llamó la «imagen científica» ${ }^{3}$ y la «imagen manifiesta», esta última expresada y enriquecida a través de la literatura y las artes. Niegan el conflicto y es tal negación la que, paradójicamente, genera la escisión.

No me extenderé más en este breve diagnóstico sobre las dos culturas. Espero que provoque un sano escepticismo sobre las motivaciones que guían tanto a los defensores de su escisión como a los que confían en una reconciliación. Esta sólo podría proceder de un reconocimiento de que existen intereses superiores a los cuales ambas esferas han de estar sometidas. Personalmente me cuesta reconocerlos y tampoco tengo una propuesta de corte metafísico sobre la división fundamental Naturaleza-Hombre, a no ser la honda convicción (no motivada racionalmente) de que es falsa. Sin duda, no es el objetivo de este trabajo reconducir el debate de las dos culturas; es más fructífero aceptar la escisión y cortar transversalmente sobre ella para distinguir elementos compartidos entre la ciencia y las artes. Lo que podría denominarse cultura de la visualidad traza una línea que atraviesa las escisiones en la tradición cultural de Occidente.

Pretendo en las páginas que siguen caracterizar la cultura científica (también la cultura técnica) como una particular cultura visual que instaura y consolida a lo largo de la historia y en su desarrollo prácticas de representación que logran -podría decirse- hacer visible lo «invisible» y configurar y estructurar nuestra intuición de la naturaleza. Desde 


\section{Cultura científica, cultura visual...}

un principio, creo conveniente recordar que las prácticas representacionales en la ciencia no se agotan en los procesos de visualización; al contrario, se extienden también y primordialmente al uso de las matemáticas y de sistemas abstractos de símbolos cuyo objetivo es la manipulación de información interpretable de forma más poderosa y eficiente. Arte y ciencia comparten, en el origen del mundo moderno, un interés común en la generación de imágenes y de otros dipositivos visualmente interpretables. Se apoyan en un mismo conjunto de prácticas y de saber hacer, prácticas que incorporan y dan lugar a una nueva comprensión de los fenómenos. La cultura visual que se gesta en el Renacimiento provocará finalmente una reforma del mismo concepto de visión y, por extensión, de la naturaleza de la cognición. Se ha insistido ya hasta la saciedad que fueron ciertas "convenciones» pictóricas surgidas dentro de las prácticas artísticas las que permitieron, en primer lugar, la proliferación de imágenes en los tratados científicos $\mathrm{y}$ técnicos de finales del siglo XV y durante todo el siglo XVI y, en segundo lugar, configuraron una particular intuición del espacio compartida por artistas y por la nueva ciencia de la matematización de la naturaleza. Lejos de mi intención poner en duda una hipótesis tan arriesgada; por el contrario, la voy a tomar como motivo para avanzar en una mejor comprensión de cómo tales prácticas pudieron ayudar a configurar el contexto epistémico de la nueva ciencia. Voy a proceder del siguiente modo: la próxima sección ofrecerá unas breves notas generales sobre el papel de la visualidad en la ciencia; tras ello, examinaré varias hipótesis sobre la contribución de las artes visuales a la aparición y consolidación de la ciencia moderna; las dos secciones principales expondrán, por un lado, los rasgos y aspectos principales de lo que podría llegar a denominarse el «humanismo visual» del Renacimiento, y, por otro lado, reconduciré la discusión a la idea de prácticas representacionales, en las que descubriré los factores que finalmente generan una dinámica propia de la ciencia frente a otras esferas. La cultura visual de la ciencia se conforma a través del examen de las condiciones de representación de sus propios productos; este examen destaca la capacidad informacional del medio representacional y la fiabilidad en la extracción de información.

\section{Visualidad y ciencia}

La ciencia pertenece, por derecho propio, a la historia de la visualidad de Occidente. Desde hace unos años, lo visual ha dejado de ser coto 
privado de los historiadores del arte o de la sociología de la imagen para invadir los campos formales y abstractos de la ciencia y la tecnología. No sin cierta razón, se ha argumentado a favor de una fertilización mutua de ideas entre la historia de la ciencia y la historia de las artes visuales ${ }^{4}$. Pero tales cruces están plagados de insidiosas trampas interpretativas si no se toman las precauciones necesarias y se evita así extraer conclusiones rápidas e injustificadas a partir de la existencia de procesos, técnicas o resultados semejantes en distintos ámbitos.

Antes de examinar cómo puede el arte visual contribuir a la ciencia, será bueno comenzar con algunas observaciones generales acerca del papel de la visualización en la ciencia. No cabe duda de que los científicos usan sus capacidades visuales, no sólo ejercitadas a través de la manipulación de imágenes mentales sino sobre todo explicitadas en bocetos y dibujos, para pensar (e investigar) sobre fenómenos concretos. La imaginación visual es una herramienta imprescidible de creatividad científica ${ }^{5}$. Einstein era explícito en sus manifestaciones: «Muy raramente pienso en palabras... Lo hago en una especie de examen, en una forma visual». El uso de elementos visuales en las publicaciones y documentos científicos nos permite adentrarnos directamente en el contexto de justificación de la ciencia, ya que son producciones públicas que pueden entrar a formar parte de una reconstrucción racional ${ }^{6}$ : sin duda, cumplen varias funciones que tienen que ver directamente con la aceptabilidad (racionalmente fundada) de los resultados expuestos. Contribuyen tanto a la exposición retórica de los argumentos como a expresar y exponer, bajo determinadas condiciones convencionales de presentación, el atractivo de las razones para aceptar o la presencia de'un nuevo fenómeno, o cierta original clasificación, o cierta novedosa generalización. En este sentido, la visualización actúa como un elemento más en la comprensión científica de los fenómenos estudiados. En qué consista tal comprensión y hasta dónde alcance (¿llega a exhibir la naturaleza en su profunda unidad o en su bien dispuesto orden? ¿resume fenómenos y observaciones de forma atractiva y directa?), no va a ser objeto de discusión: ello corresponde más bien a un debate sobre los fines y valores de la empresa científica en su conjunto que el simple examen de las prácticas de visualización no podría zanjar ${ }^{7}$.

Si la visualización juega tal papel en la comprensión y explicación dentro de la ciencia (y tómense estos términos en su sentido más estricto), la cuestión abierta - y de mayor relevancia y alcance- es determinar cómo funcionan tales dispositivos visuales. He aquí un catálogo posible de funciones particulares que pueden cumplir las imágenes en la argumentación científica ${ }^{8}$ : 


\section{Cultura científica, cultura visual...}

a) Las imágenes pueden simplemente ilustrar observaciones sistemáticas de elementos naturales.

b) Las imágenes pueden servir para sugerir, a partir de la exposición de varios elementos conectados, generalizaciones inductivas.

c) Por supuesto, desde un inicio, la ciencia utilizó las ilustraciones y grabados para presentar sensiblemente sus instrumentos $\mathrm{y}$ los experimentos realizables con ellos.

d) Otra de las funciones más frecuentes de las imágenes es la presentación de clasificaciones y sistematizaciones de fenómenos naturales.

Las formas del pensamiento científico, desde los momentos de descubrimiento hasta la presentación de resultados, están recorridas por los procesos de generación y manipulación de imágenes de muy distinto tipo: bosquejos, gráficos, mapas, diagramas, esquemas, proyecciones, fotografías, etc. Las formas no-proposicionales de pensamiento visual son esenciales para el desarrollo de la ciencia. Ya desde la aparición de las imágenes «científicas» en los tratados del siglo XV, se multiplicaron los usos a los cuales estaban dirigidas, desde la simple ilustración de las observaciones a la representación de procedimientos experimentales, desde las generalizaciones sugeridas a la visualización taxonómica, desde la mera autoilustración de fenómenos a la inserción de incluso sugerencias conceptuales. Finalmente todos estos usos se ordenan bajo la idea de llegar a hacer comprensibles los fenómenos, lo que requiere «sacarlos a la luz» por medio de procedimientos de visualización. La diversidad del orden «imaginativo» que los científicos insertan en sus tratados y publicaciones no es simplemente un instrumento de retórica sino ante todo un procedimiento de «hacer ver» aquello que permanece invisible, invisible no tanto a los ojos cuanto a la comprensión, e incluso para «hacer aparecer» aquello que, en cierto modo, puede ser irrepresentable ${ }^{9}$.

Pero hay un hecho al que no se ha prestado demasiada atención en la historia de la visualidad propia de la ciencia: los formatos en que se presenta lo visualmente accesible no tienen por qué reducirse a lo icónico; lo visual en la ciencia actúa no sólo a través de los medios imaginísticos tradicionales. La peculiaridad de la ciencia es que ha logrado multiplicar los medios de representación que apelan a propiedades visuales relevantes para ofrecer información interpretable. Voy a entender por propiedades visuales aquel conjunto de aspectos recognoscitivos que dependen del funcionamiento natural de la visión. Estos aspectos que pueden ser naturalmente detectados mediante la visión pueden ser analizados (y utilizados abstractamente) y es- 
tructurados convencionalmente para codificar información ${ }^{10}$. Atendiendo a las propiedades de color, forma, disposición espacial, tamaño, etc. se pueden diseñar diferentes medios representacionales no imaginísticos que dependen para su interpretación de la organización y estructura de elementos visuales. No existe un único medio de representación visual; la visualidad se expresa en medios diferentes, de carácter heterogéneo y que, en ocasiones, dadas las operaciones de traducción y de transformación pertinentes, se pueden conectar y combinar entre sí.

En un libro reciente, Martin Kemp ${ }^{11}$ calificaba el papel de la visualización en la ciencia como un modo de proporcionar lo que llama intuiciones estructuradas. Los actos de visión a los que nos enfrenta la ciencia no son los de la observación ingenua y desnuda de la naturaleza. La confrontación directa con el mundo se aleja a través de las «convenciones» de codificación de información en la ciencia; su inmediatez es ficticia. La ciencia articula la experiencia posible a través de sus medios de representación; en el caso de los medios visuales, conforma la intuición posible para un ámbito de fenómenos. La cuestión de interés es cómo las prácticas logran que tal estructuración actúe en una comprensión, a través de la visión, de ese ámbito de fenómenos. No puedo sino ofrecer el núcleo de una hipótesis sobre la cuestión: de lo que se trata es de manipular y seleccionar adecuadamente aquellos elementos que son detectables a través de las capacidades (naturales) de reconocimiento del sistema visual. Guiado por las claves que resaltan en tal estructuración, la comprensión generada visualmente permite extraer información sobre los fenómenos estudiados.

En este sentido, tendría muy pocas consecuencias distinguir entre visualización y visualizabilidad ${ }^{12}$, entre la posibilidad de dar una imagen intuitiva de fenómenos directamente accesibles $y$ ofrecer imágenes sin basarlas en lo que está directamente presente a la intución. Puesto que tampoco tendría justificación distiguir entre las imágenes visuales derivadas de la experiencia de los fenómenos y aquellas animadas o sugeridas a partir de las teorías sobre los fenómenos. La dificultad procede de una tensión entre decir que la teoría decide aquello que es intuible (yo diría incluso «experiencia posible») y el hecho trivial de que las capacidades de reconocimiento no son «elegibles» si se quiere ofrecer una visualización de un fenómeno. De hecho, el error procede de someter la visualidad a una cartografía de las apariencias, como habría dicho Gombrich. Tanto la transcripción perspectivista de las apariencias como las representaciones generadas a partir de teorías puramente abstractas y matemáticas ofrecen formas científicamente 


\section{Cultura científica, cultura visual...}

interesantes de estructurar la intuición de los fenómenos. La comprensión es, en ambos caso, visual, se pretenda o no un reflejo naturalista de lo que aparece ante el sujeto.

\section{El «nuevo mundo» de la visión}

¿Cómo fue posible que el orden de la visualidad se insertara como esencial en los tratados y obras científicas y técnicas? Una sugerencia que se ha abierto paso en la interpretación histórica del surgimiento de la ciencia insiste en que fue el impacto de la adopción de ciertas convenciones pictóricas surgidas en el terreno del arte las que hicieron posible que la cultura científica deviniera tempranamente una cultura iconofílica. La Revolución Científica estuvo guiada por una previa Revolución en el terreno de las artes visuales; ofreció nuevas prácticas de representación fundadas en un concepto de la visión en cuanto sometida a un orden racional y geométrico. La invención de la perspectiva dio el disparo de salida para racionalizar la visión y poder así dar la primera imagen de un espacio controlado y matematizado. Si finalmente la visión pudo concebirse como una forma de cognición, fue debido a que la experiencia misma se podría exhibir racionalmente bajo el control de leyes matemáticas que el «artista-científico-ingeniero» domina. Un doble movimiento tiene lugar: por un lado, la posibilidad de la representación requiere comprender las leyes naturales; por otro lado, toda experiencia queda controlada y racionalizada a través de la proyección de las leyes geométricas que rigen la visión y comprensión del espacio. Finalmente, en esencia, las leyes naturales del mundo no pueden sino ser leyes de la geometría.

Esta centralidad de la perspectiva en las transformaciones del inicio de la modernidad fue intuida por Panofsky en su imprescindible La perspectiva como forma simbólica. En esta obra, Panofsky defendía que las prácticas artísticas ligadas a la perspectiva ilustraban, por vez primera y con anterioridad a la matemática, un concepto de espacio sistemático, coherente. Es más, determinados avances en el campo de las matemáticas, incluida la geometría proyectiva del siglo XVII, dependían esencialmente de los estudios artísticos precedentes ${ }^{13}$. Pero su tesis fundamental no es la simple constatación de una secuencia causal de influencias entre las artes de la perspectiva y las ciencias. El concepto de forma simbólica permite sacar a la luz un aspecto más integrador en la comprensión de las condiciones de posibilidad de la cultura moderna. 
«Así, la gran evolución que supone el pasar de un espacio de agregados a un espacio sistemático llega a una conclusión provisional y, a su vez, esta conquista de la perspectiva no es más que una expresión concreta de lo que contemporáneamente los teóricos del conocimiento y los filósofos de la naturaleza habían descubierto» ${ }^{14}$.

La perspectiva es una técnica que permite expresar sensiblemente un contenido "espiritual», una concepción misma del espacio que puede manifestarse en otros ámbitos de la cultura. Las concepciones del mundo y sus intuiciones fundamentales se expresan de manera concreta a través de sus lenguajes. Encontrar la íntima ligazón entre la expresión sensible y el contenido espiritual comunicable bajo tal expresión es el objetivo de una filosofía de la cultura que analiza el desarrollo y constitución de las formas simbólicas ${ }^{15}$. Esta codeterminación particular de sensible/espiritural marca la posibilidad del avance de la cultura. De ahí la unidad del arte y de la ciencia en cada época histórica. Pueden expresar intuiciones fundamentales semejantes. La perspectiva muestra sensiblemente la forma bajo la cual se unifican y se comprenden los componentes básicos de la nueva cultura en ciernes, una cultura del conocimiento del mundo como ciencia, como orden, legalidad natural y geometrización del espacio en que los fenómenos aparecen.

«Y a partir de aquí muestra el desarrollo general de la ciencia natural exacta cómo de becho cada progreso en su planteamiento del problema y en su instrumento conceptual va de la mano de una depuración creciente de su sistema de signos... De acuerdo con su convicción fundamental, la lógica de las cosas, esto es, de los conceptos y relaciones fundamentales materiales sobre los que descansa la estructura de la ciencia, no puede ser desvinculada de la lógica de los signos. Pues el signo no es una mera envoltura eventual del pensamiento, sino su órgano esencial y necesario. No sirve sólo para la comunicación de un contenido de pensamiento conclusamente dado, sino que es el instrumento en virtud del cual este mismo contenido se constituye y define completamente. El acto de la determinación conceptual de un contenido acompaña al acto de su fijación en cualquier signo característico» ${ }^{16}$.

Para Cassirer, los signos proporcionaban, a través de actos espirituales de la conciencia, una configuración de lo sensible, que dejaba el ámbito de las puras sensaciones y entraba a formar parte del valor de una objetividad posible. Las expresiones lingüísticas (en sus diversas formas) se alejan así de la copia del mundo dado en sensaciones e intuiciones para constituir un terreno independiente, con su propia «significación» y dinámica. 


\section{Cultura científica, cultura visual...}

Sin duda, la filosofía de las formas simbólicas está animada por un idealismo de la creación espiritual que se me antoja poco atractivo; pero insiste en un punto irrenunciable: ciertas posibilidades de comprensión dentro de la cultura sólo están al alcance si se diseñan sistemas de signos y lenguajes suficientemente expresivos. Es posible retener tesis esenciales en cuanto al impacto de las artes sobre el desarrollo de los procedimientos básicos de la ciencia sin adentrarse en las lecturas idealistas. Los aspectos esenciales de tal impacto podrían resumirse así:

1. Las artes pictóricas, en cuanto que aplican la geometría y la perspectiva, contribuyen a la aparición y consolidación de la ciencia moderna.

2. El historiador tiene el compromiso de explicar cómo se produce esta contribución esencial de las convenciones perspectivistas a la ciencia. Puede inclinarse por reconocer su papel como forma simbólica o puede ver cómo responde y guía psicológicamente el modo en que el hombre se acerca al mundo y lo ve. Quizá la perspectiva contribuya esencialmente a constituir una nueva forma de comprender la metáfora del «ojo de la mente». No es que la mente en su intuición de las formas puras actúe como un ojo, sino más bien ocurre que la mente actualiza, a través de visualización que ha internalizado las reglas artificiales de la geometría, imágenes manipulables que llevan a una comprensión de las cosas.

3. Centrarse en las técnicas y convenciones de la perspectiva ayuda igualmente a dar cuenta de varios aspectos esenciales en el posterior desarrollo de la ciencia:

i) las matemáticas juegan un papel esencial en la ciencia moderna, y esta importancia se manifiesta igualmente en la racionalización geométrica del espacio que significan las técnicas representacionales en perspectiva;

ii) un mismo tipo de razonamiento se puede aplicar a la mentalidad mecanicista que incita el nuevo pensamiento científico; los libros de máquinas, llenos de imágenes y guiados por las mismas convenciones de visualización espacial, proliferan en los siglo XV y XVI ${ }^{17}$.

La perspectiva permite, pues, dar cuenta de una transformación esencial en la forma de percibir la realidad; traza un camino hacia la racionalización de la visión ${ }^{18}$, «una gramática y una sintaxis para cuantificar los fenómenos naturales mediante imágenes» ${ }^{19}$. Poder ver y poder hacer ver ciertos fenómenos estarán en función del dominio de ciertas convenciones en la presentación visual de los mismos. La visión se puede convertir en un tipo más de cognición. Sometida a 
ciertas constricciones de tipo «artificial» puede ofrecer cierta coherencia, cierta estructura. El orden está mediado por técnicas representacionales. Pero ¿cómo un aspecto tan particular y simple pudo tener consecuencias tan enormes en la transformación cultural de los siglos XVI y XVII?

$\mathrm{El}$ «nuevo mundo» de la visión se abre paso entre las prácticas, mapas, inscripciones, gráficos e imágenes de artistas, ingenieros, científicos e ilustradores. La estrategia metodológica al estudiar la gran cesura que se marca en la cultura de los siglos XVI y XVII ha de ser menos dotar a la Mente de un órgano especial (el método, por ejemplo) que capta el orden de las cosas que recopilar y analizar la cultura material que surge por doquier. Los sociólogos del conocimiento científico y la proliferación de los estudios culturales de la ciencia nos han enseñado que es mejor apelar a «causas sencillas y empíricamente verificables».

«La Gran Separación puede fragmentarse en numerosos conjuntos pequeños, inspirados y prácticos de destrezas con el fin de producir imágenes sobre las cuales poder leer y escribir» ${ }^{20}$.

Pero es cierto igualmente que no basta con atender a los instrumentos, medios de escritura o técnicas de visualización (lo que se han denominado los mediadores) y describir la ciencia como una actividad visual de mediación; es preciso situar en un contexto explicativo estas prácticas. Hay que saber hacer uso de estos elementos, de situar en su contexto específico los procesos de visualización. Sería un error tanto someterlos a la psicología y epistemología - argumenta Latourcomo dejarlos reducidos a elementos semióticos puros ${ }^{21}$. Latour, y con él otros muchos «antropólogos» de la ciencia, se inclinan por una versión constructivista que categoriza todos los mediadores visuales como móviles inmutables ${ }^{22}$ cuyo objetivo (la razón por la cual han sido seleccionados) es lograr una mejor movilización de recursos y lograr así alineaciones favorables de los mismos. En eso consisten las estructuras de micropoder que garantizan otras instituciones más omniabarcantes. Latour no quiere dejar ninguna duda respecto a esto:

«... no es la percepción lo que está en juego en este asunto de la visualización y la cognición. Las inscripciones nuevas y las nuevas maneras de percibirlas son el resultado de algo más profundo. Cuando lo que se desea es apartarse del propio camino para regresar bien equipado y forzar a otros a que se aparten de $s u$ camino, el problema principial que hay que resolver es la movilización» ${ }^{23}$.

La «nueva visión» se traduce así en maniobras de movilización a través de estos móviles inmutables que se manifiestan ante la vista 
Cultura científica, cultura visual...

del público. En otras palabras -que Latour estaría lejos de admitir-, la selección de aquellos rasgos explicativos de las prácticas y objetos culturales propios de la ciencia se hace conforme a su capacidad para reproducirse a través del reclutamiento de aliados. Desde la concreción y materialidad de los instrumentos e inscripciones hasta la formalización y abstracción de las teorías, todo es contemplado a través de esta capacidad de contribuir a la movilización de recursos.

Las prácticas de visualización se conciben entonces como procesos de intermediación en los cuales la fabricación (la construcción) se oculta a sí misma a través de un doble movimiento: por un lado, se multiplican los intermediarios; por otro lado, se hacen desaparecer todos ellos para mantener ciertas constancias. La mediación en la ciencia transcurre como in-formación y trans-formación. En la primera, algo queda «informado»: hay que prestar atención a los aspectos materiales de las inscripciones. En la segunda, se transcribe en nuevas formas lo ya informado en un doble proceso de desmaterizalización y de rematerialización. Lo realmente sustancial en las transformaciones es que pretenden al mismo tiempo retener un común «referente» (rasgos constantes) a través de los cambios y suponer que, en ello, dada la diversidad de medios (¡vehículos según la interpretación de Latour!), la in-formación sufre modificaciones radicales ${ }^{24}$. Pero en la medida en que se hacen desaparecer (a través de las exposiciones públicas en los documentos $y$ artículos) los intermediarios constructivos, se comienza a suponer una referencia que atraviesa y recorre todas las representaciones de representaciones de representaciones ${ }^{25}$. Finalmente, el resultado aparece como un acceso informacional al mundo, una especie de realismo también «construido».

Mi objetivo en lo que sigue es evaluar este tipo de hipótesis explicativas sobre el papel de la cultura visual del Renacimiento en la incorporación de la visualidad a las prácticas de la ciencia. En primer lugar, voy a reconocer una limitación esencial a la hipótesis que liga visualidad y consistencia perspectiva y geométrica: existen diversas tradiciones de lo visual durante los siglos XVI y XVII, y todas ellas impactan de algún modo en la configuración de las prácticas representacionales de la ciencia. En segundo lugar, voy a descargar a la filosofía de la cultura y de las formas simbólicas de sus inclinaciones idealistas. En tercer lugar, ofreceré una hipótesis alternativa sobre lo que unifica las prácticas representacionales de la ciencia: no será la movilización de recursos y el reclutamiento de aliados. Será, ante todo, una nueva forma de comprender la naturaleza misma de la representación. 


\section{«Humanismo visual»}

No sería exagerado afirmar que, paralelo a un humanismo de las letras, recuperación del glorioso pasado literario y científico de la Antigüedad, el Renacimiento animó un «humanismo visual» cuya influencia en la aparición y desarrollo de la ciencia moderna ha comenzado a ser estudiada ${ }^{26}$. La multiplicación de los medios para la representación visual y el desarrollo de un instrumento eficaz de comunicación visual contribuyen a desbloquear la mentalidad medieval de transmisión del saber. El científico comienza a mirar la naturaleza de manera diferente tras redescubrir el matematicismo; pero es igualmente cierto que la posibilidad de transcribir visualmente aspectos de la realidad no influye en menor medida en la mirada con que se acerca al mundo. Y es un hecho ampliamente reconocido que los siglos XV y XVI se caracterizan por la masiva producción de imágenes que acompañan a las nuevas ediciones de los tratados científicos y técnicos. El interés creciente por incluir representaciones visuales fieles y ajustadas a la realidad de las cosas va a trastocar la concepción de un universo desconocido poblado por seres fantásticos, fabulados, simbólicos o religiosos. Adentrarse en la terra incognita a través del descubrimiento exige un registro sincero y fidedigno de lo que se encuentra en el camino, una taxonomía de lo realmente visto tal y como ha sido visto.

El valor de las imágenes durante la Antigüedad era escaso, debido no sólo a una clara expulsión del reino de las verdaderas realidades y a ser consideradas, por tanto, generadoras de un mundo cambiante y engañoso, sino también a una imposibilidad técnica de ofrecer copias e imitaciones fieles de los originales. El cambio de mentalidad de la Antigüedad al Renacimiento se resume perfectamente en la contraposición de las dos siguientes citas. La primera es de Plinio y alude a las representaciones pictóricas en botánica.

«Hay algunos escritores griegos que han tratado este tema [botánica]... Entre ellos, Crateuas, Dionisio, y Metrodoro, adaptaron un método muy atractivo de descripción, aunque uno que no ha hecho más que probar las notables dificultades que le esperaban. Era su plan dibujar las diversas plantas en colores, y añadir entonces una descripción escrita de las propiedades que poseían. Las imágenes, sin embargo, son muy aptas para engañar, y más particularmente donde se requiere un gran número de tintes para una imitación exitosa de la naturaleza; además, la diversidad de copistas a partir de las pinturas originales, y sus grados comparativos de habilidad, se sumaban considerablemente a las oportunidades de perder el necesario grado de semejanza a los originales» ${ }^{27}$. 


\section{Cultura científica, cultura visual...}

La segunda procede de un tratado germánico del siglo XV conocido como Gart der Gesundheit (1485).

"Y cuando estaba en medio de mi obra de dibujar y pintar las hierbas me dí cuenta de que muchas hierbas nobles no crecían en esta tierra alemana, por lo que, excepto por oídas, no podría dibujarlas en sus verdaderos colores y forma. Por eso, dejé inacabada la obra que había comenzado y mé dediqué a la pluma... Así, con el temor de dejar sin hacer esta obra comenzada pero no acabada, y también con la pretensión de que mi viaje sirviera no sólo para la salvación de mi alma sino de todo el mundo, tomé conmigo un pintor de entendimiento y con una mano sutil y experta. Y así viajé... Y, al viajar por estos reinos y tierra, aprendí diligentemente las hierbas que había allí y las pinté y las dibujé en sus verdaderos colores y formas» ${ }^{28}$.

Una doble convicción se halla tras este cambio de actitud. La primera tiene que ver con el mismo valor de las imágenes como transmisoras de conocimiento; sometidas a un código sintáctico que se irá enriqueciendo en el desarrollo mismo de las técnicas, los «enunciados» visuales van a convertirse en medios fiables para registrar conocimientos de lugares y objetos hasta entonces innaccesibles o sometidos a las variaciones representacionales de las fábulas, de las historias contadas. La segunda es más que una convicción una posibilidad abierta por el desarrollo de las mismas prácticas de representación y de reproducción de las imágenes, que hacen falso el veredicto de Plinio respecto a su poca fidelidad a los originales: los artistas desarrollarán técnicas comunes para el registro fiel y experto de los detalles «científicos» relevantes. La lenta desaparición de los copistas durante el siglo XVI y la sustitución por la reproducción mecánica mediante xilografías, aguafuertes y grabados permitió igualmente la uniformidad en estas reglas de composición de los dibujos. En consecuencia, la negatividad metafísica que la Antigüedad asociaba al terreno de las imágenes se ve superada por la positividad del fiel registro de las apariencias ${ }^{29}$.

Así, se presentaron al público numerosos tratados científicos (y no científicos) ilustrados. $\mathrm{E}$ incluso mucho antes, toda una tradición de códices y de tratados no publicados por los médicos-astrólogos, los ingenieros sieneses o florentinos había desarrollado técnicas de representación cuyo impacto sobre el avance posterior es definitivo ${ }^{30}$. Desde la aparición en 1472 del De re militari de Valturius, cuyo objetivo principal era la comunicación deliberada de información técnica para la guerra (aunque sin adoptar las técnicas perspectivistas de los códices de un Tacola, un di Giorgio o un Leonardo), se sucedió la publicación de tratados botánicos y medicinales (en 1480, el Pseudo-Apuleyo, un 
manuscrito botánico del siglo IX; en 1484, el Latin Herbarius; en 1485, el Gart der Gesundheit; en 1491, el Fasciculus Medicinae de Johannes de Ketham; o el Herbarum vivae eicones de Brunsfels en 1530; o el famoso De Stirpium historia de Fuchs en 1545), tratados anatómicos (C. Estiene con su De dissectione partium corporis humani en 1545 y Vesalius con su Fabrica humani corporis en 1543), historias de animales (Historia animalium de $\mathrm{K}$. Gesner en 1554), o enciclopedias, o libros de viajes, o de procedimientos de escritura, etc. Sirva como ejemplo del cambio de actitud en la representación de los seres naturales la comparación que K. Gesner introdujo en su Historia animalium entre una imagen procedente de los bestiarios imaginarios medievales de las salamandras y lo que él consideraba una representación realista y fiel de las mismas. El enfrentamiento "retórico» de ambas imágenes se ordenaba hacia un contraste entre las visiones fabulosas de seres naturales y las representaciones de un mundo real y natural tal y como se puede ver.

En resumen, desde mediados del siglo XV, la cultura europea, que en una cierta línea se volvía hacia el pasado para la recuperación del esplendor grecolatino, al mismo tiempo empezaba a considerar el libro de la naturaleza como fuente de conocimiento en la medida en que los descubrimientos quedaran registrados fielmente por las expertas manos de los artistas. Un propósito didáctico innegable recorría los tratados científicos ilustrados y los tratados de máquinas de los siglos XV y XVI, que se vio reforzado por una tendencia al naturalismo permitida por el desarrollo de técnicas de presentación de las imágenes: Leonardo, en sus cuadernos, ofrece todo un catálogo de estas técnicas mediante el uso de escorzos, la presentación de la estructura tridimensional de los objetos, sombreado y relieve de las partes, imágenes expandidas de los objetos, etc. ${ }^{31}$ Artistas, científicos e inventores participan conjuntamente en esta revaloración del mundo de las imágenes y abren la puerta a una sustitución del modelo de la evidencia del libro transcrito (autoridad) por el modelo de la evidencia que procede del mundo y que aparece como siendo sobre la verdadera realidad de las cosas. En esta transformación, el Renacimiento proporciona un impulso hacia el pensamiento científico moderno.

Pero ¿qué relevancia podría tener esta preocupación artística por las imágenes, aunque abundara en sus pretensiones de fidelidad, naturalismo y didactismo, para la constitución de la ciencia clásica de la mecánica, modelo primigenio de la «revolución científica»? ¿No son claramente reconstrucciones poco justificadas aquellas que pretenden ligar el desarrollo de las técnicas de las imágenes en los tratados, 
especialmente de máquinas, con la preocupación por la mecánica desde finales del XVI? ¿Y qué pueden tener que ver con la revolución galileana y su rechazo de las concepciones dinámicas aritstotélicas? ¿No son claramente exageradas las declaraciones de Panofsky de que fueron estas innovaciones técnicas del arte del Renacimiento las que pusieron los fundamentos de la revolución científica? En todo caso, ¿cuál podría ser la contribución principal del desarrollo de los medios de representación visual del mundo natural para la aparición de la ciencia moderna galileana, bien sea en sus aspectos metodológicos, bien sea en sus contribuciones más teóricas?

Aún podría, no obstante, apelarse a la fructífera distinción kuhniana entre dos tradiciones en la ciencia moderna: la tradición galileana y la tradición baconiana, cuyo grado de desarrollo fue muy diferente desde principios del siglo XVII. Su diferencia más importante residía en el papel de las observaciones en la construcción de su corpus teórico: las ciencias clásicas, matemáticas, verdadero núcleo de la primera revolución científica, no fundaban su avance en la recopilación de datos sofisticados (quizá la excepción en este caso sea la astronomía, por supuesto) y elaborados a través de intervenciones experimentales, sino que «los datos que exigía su desarrollo fueron de tal naturaleza que los podía proporcionar la observación cotidiana, a veces perfeccionada y sistematizada modestamente» ${ }^{32}$. Las ciencias baconianas, por el contrario, no sólo insistieron en la necesidad de observaciones sino que transformaron los mismos procedimientos de observación y de obtención de experiencias: «los experimentalistas baconianos... insistieron en las comunicaciones exactas y pormenorizadas» ${ }^{33}$ de las observaciones y experimentos ${ }^{34}$. ¿No podría entonces sugerirse la continuidad de las preocupaciones renacentistas por la fiel representación en imágenes con el desarrollo de las ciencias baconianas? Incluso aunque fuera erróneo conectar su importancia con la aparición de las ciencias clásicas, se podría ver en el registro de observaciones mediante ilustraciones cada vez más precisas y expertas una inspiración de las técnicas de observación que exigirán las futuras ciencias experimentales.

El contraste entre dos formas de considerar la experiencia durante el Renacimiento tanto por parte de artistas como de científicos ayudará no tanto a incidir en esta separación, sin duda justificada en cierto nivel, entre ciencias clásicas y baconianas, cuanto a enfatizar algún aspecto en común que afecta a la consideración de las observaciones como evidencias no desdeñables en la interpretación de libro de la Naturaleza. Se trata de dos tendencias, aparentemente contrapuestas, en la consideración de lo que hoy se llamarían «datos observables»: 
la primera de ellas acentuaría el sometimiento de lo que se ve a un orden racional (definible matemáticamente); la segunda insistiría en el registro fiel y experto de lo que se ve mediante descripciones pormenorizadas y minuciosas.

Ambas tendencias se asocian con dos tradiciones artísticas para el tratamiento y consideración del mundo de las imágenes. Quizá uno de los máximos exponentes de la primera sea L. B. Alberti y su apología del «artista racional»: hay que someter las experiencias al orden de las proporciones en un proceso activo de representación. En la idea de «proyectar» o «diseñar», en cuanto maquinación activa del artista, éste busca desentrañar el orden racional de la experiencia. El artista es un actor, observador y conocedor como cuantificador. La perspectiva constituye un modelo de control de las apariencias, de búsqueda de la consistencia óptica y geométrica de la visión. Dentro de esta tradición, la pura recopilación de datos no tiene sentido: sólo importa su inserción en un esquema racional proyectado por el artista, su despliegue bajo cierto orden. Dos aspectos habría que retener de esta concepción de la experiencia: la primera es que no es separable de su aspecto activo (del hecho de representar); la segunda es que adquiere su sentido mediante el sometimiento a ciertas condiciones que proceden de la forma representacional que el sujeto proyecta (diseña) para el registro o, en otras palabras, no hay observaciones neutras, ingenuamente anotadas o grabadas en los intelectos.

Aún se puede hablar de una forma diferente de «ojo activo» cuyo tratamiento de las apariencias obedece menos a los dictados de «racionalidad» de una estructura matemática subyacente que a la precisa y atenta descripción y cartografiado de la realidad. Es esa tendencia la que, en un extraordinario trabajo, S. Alpers asocia con las cumbres de la pintura holandesa del siglo XVII. Frente al mundo de la pintura italiana y sus representaciones historizadas y literarias, dramáticas, el arte de la pintura holandesa es el de una descripción de la realidad visible, que se inspira en prácticas de observación precisas y expertas, ayudadas de nuevos instrumentos técnicos (microscopios, telescopios), y que transcrita pacientemente en imágenes ofrece un testimonio fidedigno de la realidad ante los ojos, del teatro de la naturaleza y de los «nuevos mundos» que esos instrumentos abren a la visibilidad.

«Un mirar atento, transcrito por la mano - lo que podríamos denominar la técnica de la observación-, permitía documentar la multitud de cosas que componen el mundo visible» ${ }^{35}$.

Por consiguiente, en la pintura holandesa, se muestra esta tendencia «baconiana» de las ciencias naturales al registro de los hechos naturales 


\section{Cultura científica, cultura visual...}

mediante el desarrollo de prácticas de observación. El proceso, como tal, no es menos activo: la observación es un hacer representaciones, que en numerosas ocasiones ha de estar mediado por el desarrollo de instrumentos. El ojo mismo es un instrumento, cuyas condiciones de funcionamiento deben ser investigadas para una evaluación de sus resultados. El mecanismo de funcionamiento visual es un mecanismo «representacional», "pictórico», en esencia. Como cualquier otro instrumento, está sometido a ciertas condiciones de fiabilidad y, por tanto, de falibilidad. La observación deja de ser una cuestión de pasividad y de registro neutro de imágenes. Artistas y científicos comparten un interés en el desarrollo de técnicas para permitir ver, para hacer visible a través de las imágenes. La metáfora del «descubrir» codifica este proceso de visualizar.

El aparente contraste entre un «interpretacionismo racional» de la experiencia y un extremo descriptivismo queda, pues, relativizado en el momento en que la experiencia ha de someterse a los criterios de evaluación que hacen de las representaciones algo fidedigno, fiable. Tanto en un caso como en el otro, el artista y el científico determinan criterios de aceptabilidad de los datos como evidencia de algo que pasa a ser visible. Sin duda, la nueva cultura visual redefine el ver y los objetos del ver (representaciones), y el representar y la mirada del representar, y lo hace a partir de prácticas de representación activas, selectivas, «atentas», expertas. Pero esa cultura que hace móviles los «objetos» e intensifica la inmutabilidad de sus «inscripciones» se orienta hacia una comprensión de sus propias prácticas de representación, de «visión», para dotar al artista y al científico de la evidencia con la que conoce, descubre, nuevas realidades, la terra incognita que espera al conquistador y de la que da testimonio a través de las representaciones que ejecuta.

Así se expresa Hooke en la introducción de su Micrografía:

«He emprendido aquí esta vía, no porque no haya multitud de observaciones útiles y agradables aún por recoger, lo bastante obvias sin necesidad de recurrir al arte, sino tan sólo para promocionar el uso de ayudas mecánicas a los sentidos, tanto para la inspección del mundo ya visible como para descubrir muchos otros hasta ahora desconocidos, de manera que, como el gran conquistador, nos sintamos conmovidos por no haber vencido aún un mundo, siendo así que hay tantos otros por descubrir, sirviendo cada notable mejora de los telescopios y microscopios para producir nuevos mundos y terra incognita ante nuestra vista» ${ }^{36}$.

La praxis de la observación, tanto en la ordenación racional de las experiencias según principios geométricos como en el registro fi- 
dedigno de lo que se muestra a los instrumentos, proporciona una experiencia coherente del mundo, a modo de testimonio visual contrastable con el autoritativo testimonio libresco, en la medida en que deja de ser el mero resultado de un «ojo pasivo» y considera las mismas condiciones de su producción, en un movimiento reflexivo que establece la fiabilidad del proceso (las posibilidades de error) y, consiguientemente, su aceptación como evidencia en la tarea de interpretar el mundo.

\section{Interludio: la cultura material de la ciencia}

Una convicción, compartida ampliamente por los estudios de la ciencia en la actualidad, guía esta breve e incompleta reconstrucción histórica: los objetos primarios en el estudio de la ciencia no son $\mathrm{ni}$ las teorías ni los objetos intelectuales sino las prácticas y elementos materiales de la ciencia. Dentro de los filósofos, I. Hacking ha insistido en que la actividad teórica propia de las ciencias modernas (ciencias de laboratorio) es resultado de prácticas instrumentales y experimentales. La estabilidad cognitiva implica una relación entre "pensamientos, actos y manufacturas». La cultura de la ciencia es una cultura pragmática y su estudio debe dirigirse a los modos de producción y emergencia de significado en marcos materiales concretos e históricamente situados ${ }^{37}$.

Voy a partir de un presupuesto naturalista en el estudio de la cultura $\mathrm{y}$ a suponer que debe ser conectada con las ciencias cognitivas ${ }^{38}$. El presupuesto naturalista exige que, entre las causas y efectos que configuran una cultura y sus transformaciones, se encuentren únicamente elementos aceptables dentro de una ontología naturalista. De ahí se sigue que la mejor opción no puede ser apelar a estructuras profundas o elementos simbólicos sino a elementos reconocidos dentro de la ciencia cognitiva, como son las representaciones que tienen sus propias condiciones de realización naturalista. El resultado es una concepción materialista de la cultura en la que los aspectos culturalmente describibles han de tener algún tipo de realizadores físicos. Una propuesta aceptable sería sostener que la cultura no es sino un conjunto de producciones públicas dentro de un entorno tales que estas producciones tengan entre sus causas y efectos representaciones mentales. La clave en la caracterización de la cultura está, pues, en la aclaración de qué son tales producciones públicas, una vez que las ciencias cognitivas nos han ofrecido - al menos provisionalmente - un concepto aceptable de representación mental. Entre las producciones públicas, se encuentran las conductas abiertas y las prácticas de los individuos, elementos 
Cultura científica, cultura visual...

materiales que han sido el resultado de la transformación y selección de individuos en el entorno y lo que podríamos denominar «representaciones públicas», un tipo de producciones públicas que revelan su carácter representacional y que actúan básicamente en el terreno de la comunicación. La cultura se sostiene sobre mecanismos de reproducción y de transformación de producciones públicas.

La cultura de la ciencia no es pues sino el agregado de producciones públicas que, dentro de un contexto, provocan dinámicas específicas de intercambios informacionales y una distribución de representaciones que pueden llegar a ser compartidas de manera duradera dentro de un grupo humano. Exteriormente, la cultura de la ciencia se hace manifiesta en formas de conducta, prácticas, objetos e instrumentos materiales, y en representaciones públicas, entre las que se encuentran las inscripciones visuales, matemáticas o de cualquier otro tipo. Los sistemas culturales se sostienen y reproducen a través de la interacción que se produce entre las representaciones mentales de los agentes individuales y las representaciones públicas que exteriormente están dadas a la interpretación según las constricciones que cada contexto ha impuesto selectivamente.

Toda actividad cognitiva (de la ciencia, en nuestro caso) se organiza en torno a prácticas que «movilizan» representaciones de todo tipo a la hora de ejecutar la computación y manipulación de información requeridas para la resolución de problemas. De este modo, la ciencia determina o fija un contexto en el que se desarrolla su actividad cognitiva; dentro de él, se genera un conjunto de representaciones públicas que son interpretadas por los agentes como provisoras de información fiable. Paradigmáticamente, en la ciencia moderna, el origen, la manipulación y el control de la información están sometidos a una evaluación rigurosa en cuanto medios públicamente fiables de codificación y extracción de información. Puede decirse que someter a examen este proceso de generación y manejo de representaciones supone al mismo tiempo una transformación del sujeto epistémico. La ciencia moderna surge como un contexto en que se constituyen y reproducen tanto sus prácticas como el sujeto garante de su continuidad ${ }^{39}$.

\section{Prácticas representacionales}

La cultura científica incorpora una cultura visual. Los procesos de visualización producen sistemáticamente representaciones públicas evaluables conforme a los criterios exigidos por el sujeto epistémico 
de la ciencia. Para ello, la ciencia reconoce que cada representación no se explica a sí misma; una representación lo es dentro de un amplio proceso sometido a evaluación; es necesario examinar constantemente las condiciones de producción que conducen a un elemento visual. Y esto es posible sólo si se comprende cómo se cumple la función representacional; la cultura moderna hace explícito el funcionamiento interno de los procesos representacionales. El hecho de que la cultura moderna haya sido capaz de poner al descubierto este mecanismo interno del representar explica el cambio sufrido por las prácticas de producción y de transmisión de conocimiento que identificamos con la ruptura epistemológica (científica) de la Modernidad. Es el surgimiento de prácticas que finalmente hacen explícita la naturaleza de la representación lo que hará posible que la ciencia diseñe y use cada vez un mayor número de medios representacionales (para la visualización, entre otras cosas), medios que le permitan resolver sus tareas cognitivas propias.

Pero antes de adentrarnos en las prácticas de representación, conviene precisar algo más la noción misma de práctica. Es, sin duda, un concepto omnipresente en los ambientes sociológicos, antropológicos y filosóficos, y está sometido a ciertas tensiones y a demandas explicativas que, en ocasiones, son incongruentes. Por un lado, sugiere un contraste con la actividad teórica, como ejecución de una acción (relación de la teoría con su práctica); por otro lado, refiere a secuencias de acción repetibles, rutinas o hábitos de la actividad cotidiana (del hombre de la calle o del científico); finalmente, remite a entidades espaciotemporales cuya continuidad y estabilidad se basa en una coordinación de acciones acompañada de una particular comprensión.

Son los estudios sociales de la ciencia y la tecnología los que han insistido en que tal concepto puede ser de utilidad a la hora de dar cuenta del éxito de la ciencia. Generalmente se asume la idea de que las prácticas son una forma de conocimiento inarticulado, tácito, compartido por los miembros de una comunidad que da cuenta de las regularidades empíricas detectables. Pero si es así, se enfrenta a problemas respecto a la posible transmisión de tal conocimiento, a su reproducción y, sobre todo, respecto a su papel causal en cuanto «algo» socialmente compartido ${ }^{40}$. El problema surge, ante todo, porque la explicación no puede apelar a la realidad psicológica previa de los sujetos de la práctica (lo cual, por otro lado, sería aún insuficiente para el problema de la transmisión) ni a los ciclos de reproducción cultural mediados por regularidades públicas reconocibles. Las prácticas en las que han insistido los estudios sociales y culturales de la ciencia parecen, pues, constituidas por habilidades intransferibles de modo 


\section{Cultura científica, cultura visual...}

formal mediante un aprendizaje explícito. La cultura no se enseña, se absorbe. Es más, convierte a los conocimientos en saberes locales, que necesitan ser redescubiertos y reinventados en cada nuevo lugar, que forman parte de tradiciones estables, incomunicables.

Una práctica es un complejo de conducta abierta y dotación cognitivo-representacional que genera hábitos y disposiciones a la acción identificables. Toda práctica incorpora un saber cómo llevar a cabo una secuencia de acciones materiales de transformación del entorno. Así, prioritariamente, también las prácticas representacionales serán examinadas como actividades materiales. Un segundo aspecto de las prácticas es su radical carácter temporal; una práctica está caracterizada por una dinámica procesual con ciertos patrones de estabilidad ${ }^{41}$. Por supuesto, las prácticas se exhiben y se estabilizan localmente, en un contexto cultural concreto, de tal manera que supone que su dominio requiere un elemento compartido por los individuos que están sometidos al mismo entorno cultural. Pero ¿hay algún modo de que aquello compartido, una forma de saber hacer, sea personal (como un hábito), socialmente compartido e históricamente estable? Es aquí donde una teoría correcta del saber práctico entra para caracterizar estas entidades históricamente estables y socialmente compartidas. Saber práctico denota un elemento normativamente evaluable, cuya normatividad consiste en cierta comprensión de las condiciones de éxito del esquema o esquemas de acción que estructuran una competencia práctica. La fijación de las condiciones de éxito y de la comprensión de las mismas se realiza mediante procesos de variación/selección en aprendizajes por la práctica. Todos estos procesos de aprendizaje armonizan una doble dimensión: la conducta abierta y la organización cognitiva de los agentes. Por eso, su adquisición no es misteriosa y aún mantienen un elemento que podría denominarse «tácito», en el sentido de las ciencias cognitivas. La supuesta reproducción cultural debe abordarse desde esta perspectiva de la integración de elementos públicos y de representaciones mentales de los sujetos involucrados. En un sentido, pues, el conocimiento estará inscrito en las acciones, en los cuerpos; en otro, se depositará en manifestaciones públicamente accesibles.

Aquellos esquemas de acción o hábitos cognitivamente estructurados cuyo objetivo es producir representaciones, es decir, dejar información depositada en elementos materiales integrados en sistemas públicos interpretables son denominados prácticas representacionales. $\mathrm{Mi}$ anterior caracterización del concepto de práctica permite extraer directamente ciertos aspectos aplicables a las prácticas de representación: la producción de representaciones requiere la adquisición de un saber 
hacer sobre un lecho básico de capacidades cognitivas compartidas; pueden ser caracterizables externamente por los instrumentos y dispositivos materiales que ayudan a plasmar e inscribir información sobre un elemento físico; además deja abierto un ámbito de posibilidades y oportunidades de acción y de estructuración del pensamiento. Es un requisito indispensable que las producciones públicas representacionales que son resultado de tales prácticas se inserten dentro de expectativas compartidas por un grupo social. Generalmente, estas convenciones establecen un «código» que permite la interpretación de las producciones. De hecho, las prácticas representacionales también se sostienen sobre grupos sociales que comparten las claves para la actualización de los hábitos, su transmisión y reproducción.

La ciencia es una cultura de generación y corrección de prácticas representacionales. Ya el propio diseño de «lenguajes técnicos» es una forma básica de práctica representacional que deriva de una regimentación del lenguaje natural. Las técnicas de visualización son esenciales en la generación de tradiciones para la transmisión de conocimiento fiables. Requieren el diseño de aparatos de registro que detecten información y la incorporen a un soporte material, así como de lenguajes de manipulación y transformación de esa información. Si la visualización se comprende como una práctica representacional es porque las imágenes producidas están guiadas por un proceso de «racionalización» o «estructuración» tal que hagan ver.

Pero hay un rasgo esencial sin el cual es imposible desarrollar una cultura de las prácticas de representación. Ya hemos dicho que el saber hacer propio de la estructura de los esquemas de acción y hábitos de una práctica exige cierta comprensión de las condiciones de éxito de la misma. Así es imposible el desarrollo de las prácticas representacionales sin atender a las condiciones mismas del acto del representar. Es más, la mejora y corrección de las prácticas permitirá avanzar en la comprensión misma de la naturaleza de la representación. Entre las oportunidades abiertas por el mismo hacer está la reforma del pensamiento. Las prácticas de representación visual se verán acompañadas de un cambio en el mismo concepto de la visión.

Las prácticas de representación no son posibles sin el diseño y uso de medios representacionales. Es obvio que toda representación pública requiere de un soporte material. Tales soportes son rastros intencionalmente producidos e interpretables. Es preciso distinguir para cada representación el soporte físico del símbolo, aquello en virtud de lo cual es una representación de ciertos estados (su contenido) y el formato bajo el cual se hace accesible la información que porta la 
representación sobre el objeto. Es un error, numerosas veces cometido, confundir el medio representacional con el soporte material que «transporta» la información.

Los medios representacionales públicos son un tipo de artefactos simbólicos en los que se deposita información interpretable; información interpretable es aquella que es capaz de extraer un sistema cognitivo que trata a una señal no como algo que se decodifica y porta información sino como algo dotado de contenido. Además, los medios representacionales son artefactos simbólicos que forman parte de la memoria semántica externalizada de un sistema cognitivo complejo ${ }^{42}$. Por eso, se puede hablar de estos medios como un tipo especial de recursos cognitivos externos que se activan para la resolución de tareas en coordinación con recursos internos (representaciones mentales) de los sistemas cognitivos.

Sin ser exhaustivo, se podría decir que un medio representacional se caracterizaría por los siguientes rasgos:

1. el tipo de información que hace accesible, pues cada medio delimita los accesos cognitivos a un entorno informacional; estos accesos están diseñados según el uso que el sistema cognitivo haga de ese medio en sus tareas de resolución de problemas;

2. la forma en que se manipula la información en el interior del sistema representacional, dependiente de los operadores del sistema;

3. la posibilidad de traducir esa información a otros formatos y a otros medios representacionales y la capacidad de coordinarse con otros medios representacionales a través de las transformaciones adecuadas;

4. su poder expresivo y capacidad computacional;

5. el tipo de recursos o capacidades cognitivas internas asociadas al uso e interpretación de las representaciones externas ${ }^{43}$.

Un estado representacional en un medio determinado es una disposición de elementos físicos tales que, dependiendo de los formatos y los códigos en que esté, da pie a una posible interpretación. No está excluido, además, que cada medio incluya varios formatos representacionales diferentes y distintos tipos de códigos. Además, los medios pueden estar diseñados para coordinarse con otros medios y permitir así una mayor capacidad computacional. De hecho, las tareas de computación y de extracción de información van a ser dependientes tanto de la posibilidad de integración de formatos como de coordinación de medios. 
Por tanto, dejar en el mundo objetos simbólicos, representacionales, cuyas propiedades informacionales sean aprovechables computacionalmente consiste en construir una memoria semántica exteriorizada, poner un trozo de la mente (medio representacional) en el mundo. Si una «traza» en el mundo es referida a su origen intencional, entonces podría ser interpretada como un rastro que cumple su función de indicación (según regularidades informacionales) y ser considerada como una representación. Para que tal traza actúe como un medio representacional, se deben cumplir al menos dos condiciones:

a) el sistema de símbolos (de huellas) ha de tener cierta complejidad estructural interna;

b) la huella debe insertarse dentro de contextos interpretativos que involucran capacidades metarrepresentacionales.

Esto hace que toda interpretación de los signos o huellas del mundo no sea evidente por sí misma; sólo prácticas compartidas entre los miembros de una cultura hacen evidentes ciertas interpretaciones de las «huellas» en el mundo como medios representacionales.

Profundizar en la comprensión de la naturaleza de las representaciones no es primariamente una tarea teórica durante el Renancimiento; la comprensión avanza a través del dominio de técnicas de representación, como el dominio de la perspectiva. En el saber hacer representacional se someterá a un sistemático escrutinio la relación misma de representar. $\mathrm{Y}$ esto será posible porque las capacidades metarrepresentacionales que están a la base de la interpretación de los medios se hacen explícitas a través de esas prácticas. Las técnicas de perspectiva se muestran explícitamente como técnicas de representación. El diseño de medios representacionales públicos se apoya sobre este dominio explícito de la capacidad metarrepresentacional.

Pero ¿en qué consiste la metarrepresentación? Aquí no puedo ser sino esquemático y más parco en explicaciones que en lo anterior ${ }^{44}$. En el caso de los sistemas cognitivos, adquirir una capacidad metarrepresentacional consiste en adquirir una sensibilidad sistemática a las representaciones en cuanto que representaciones o, en otras palabras, una sensibilidad a cómo se establece una relación representacional. Por tanto, metarrepresentar no puede consistir simplemente en tener representaciones de representaciones (o re-representaciones), sino en que tal representación muestre la relación representacional en un medio representacional suficientemente rico y complejo para soportar tal expresión. De este modo, el contenido de la representación 
es representado bajo ese medio representacional y concebido en cuanto contenido. Como ha señalado Fernando Broncano, esto permite, en primer lugar, entender cómo los objetos simbólicos, portadores de información, pueden equivocarse y cómo pueden ser construidos para engañar (de ahí el uso de la perspectiva en los trampantojos); en segundo lugar, da la capacidad de contemplar el contenido «desde dentro» $\mathrm{y}$ «desde fuera»; estamos inmersos en el contenido de nuestras representaciones, pero «exploramos» cómo la representación remite más allá de sí misma. En eso consistirá el ejercicio de la reflexión y el examen de las condiciones de fiabilidad de las prácticas representacionales.

«El diseñador, constructor o usuario [de un artefacto representacional] debe poseer una estructura cognitiva que le permita observar «desde dentro y desde fuera" el proceso físico en tanto que proceso representacional. Desde dentro, porque debe «leerlo» o interpretarlo como una representación, desde fuera porque debe atender a los procesos causales que transportan fiablemente información» ${ }^{45}$.

Así, pues, no por casualidad el siglo XVI es rico en representaciones que toman como objeto las prácticas representacionales mismas; nos encontramos con cuadros sobre la pintura en perspectiva, sobre la naturaleza de los espejos o el valor de los mapas y la cartografía. El dominio de la perspectiva no consistirá sólo en una geometrización y control del espacio físico en el cuadro; supondrá esencialmente un examen de las condiciones mismas en que la realidad se deja ver en la representación. Como bien se sabe, su base está en el reconocimiento o comprensión práctica de los invariantes internos que se derivan de los cambios de localización espacial. Por tanto, el que domina la práctica es capaz de transformar un objeto visto desde una posición en el objeto en cuanto visto desde otra posición. Supone un dominio de la visualización porque es capaz de entender en qué consiste la capacidad repesentacional que se deriva de las técnicas de representación en perspectiva. Quien domina tales técnicas es capaz de utilizar los operadores de transformación relevantes dentro de un medio representacional para explotar la información que es representable en ese medio. Y, por ello mismo, es capaz de sostener ciertos contrafácticos sobre qué información sería visible si se cumplieran determinadas condiciones de la representación en perspectiva.

Ahora visualizar ayuda a descubrir, a desentrañar, a sacar a la luz. Podemos entonces comprender la supuesta paradoja que Panofsky creía ver en las prácticas de representación en perspectiva: 
«Así, la historia de la perspectiva puede, con igual derecho, ser concebida como un triunfo del distanciante y objetivante sentido de la realidad, o como un triunfo de la voluntad de poder humana por anular las distancias; o bien como la consolidación y sistematización de mundo externo; o, finalmente, como la expansión de la esfera del yo» ${ }^{46}$.

No es una paradoja; es la condición básica de la estructura metarrepresentacional: comprender la naturaleza del representar es ser capaz de situarse dentro y fuera del proceso de relación con el mundo. En un sentido, siente la presencia del «yo» de la representación; en otro, se distancia y contempla cómo el mundo informa la representación. Subjetivación y objetivación son como aspectos inseparables de un mismo proceso.

Por tanto, la objetividad pretendida a través de las prácticas representacionales se asegura reconociendo y ocultando al mismo tiempo la presencia de la subjetividad. Ver implica saber situarse para ver. Del mismo modo, toda visualización generada a través de prácticas representacionales sometidas a los criterios de aceptabilidad en el contexto cognitivo de la ciencia ha de tomar en cuenta y evaluar el lugar desde el cual se realiza la visualización. Las prácticas de visualización en la ciencia incorporan un aprendizaje sobre las condiciones de fiabilidad de sus resultados, aprendizaje que se hace posible a través de explotar la comprensión de la relación representacional que opera en ellas. Si a algo contribuyen el sometimiento geométrico de la visión al esquema perspectivo o el desarrollo de prácticas detallistas del registro en imágenes de lo observado, es a establecer condiciones precisas para el ver, que incluyen un saber situarse para ver y registrar lo visto, y una reflexión sobre el medio e instrumento de la visión. Es observación guiada, orientada al discernimiento, es representación racionalizada, consciente de sí y de su producción.

El valor último de la experiencia dependerá de su sometimiento al «arte», al correcto funcionamiento de las técnicas de representación y de las extensiones «instrumentales» del ver. El científico comienza a evaluar los resultados de sus procedimientos por la posición que él ocupa en la tarea. Las prácticas representacionales han de atender a las condiciones del acto de representar y a la posición del sujeto de representación como condición de posiblidad de la misma representación. Sin duda, las técnicas de representación van a permitir comprender mejor la relación del sujeto de la representación y la posibilidad de su acceso al mundo, y todo ello dentro de un terreno de producciones representacionales públicas, convencionales. 


\section{Conclusión}

La última fenomenología husserliana, la de la Crisis de las ciencias europeas, nos había legado una concepción del origen de la modernidad como fundada en el a priori histórico de la ciencia. La racionalidad moderna se origina a través de la idealización galileana de la geometría y la matematización del mundo. Recorrer el dominio de las cosas que són es un modo de considerarlas bajo la idealización matemática. La aplicación de Panofsky de la filosofía de la cultura desarrollada por Cassirer enfatizaba el hecho de que tales transformaciones requieren ciertos lenguajes o medios de expresión concretos; la perspectiva en el arte equivalía en el terreno de la cultura a una forma de aprehender el mundo bajo las leyes de consistencia geométrica, leyes que hacen intuible el mundo de modo racional. El arte impacta en la formación del espíritu científico al ofrecer herramientas simbólicas que muestran la coherencia del espacio y la consistencia geométrica de la visión. Pero lo hace menos por un acto de creación espiritual de la conciencia que por las prácticas materiales que dominan los artesanos, maestros pintores y, con ellos, después la cultura que se difunde en los textos escritos. La importancia de la perspectiva en el origen de la ciencia moderna sólo se puede contemplar desde una doble dimensión: su inclusión en una cultura general de la visualidad que se configura y se enriquece lentamente desde finales del siglo XV y una interpretación material y práctica de los procedimientos perspectivistas.

Se multiplicarán entonces los instrumentos, las inscripciones, las imágenes; poblarán los tratados y serán objeto de discusión enconada. Las posibilidades abiertas para trasladar la información, para movilizar la información, serán crecientes. Pero el contexto que se articula en torno a los nuevos científicos atenderá principalmente a un aspecto especial de todos esos recursos cognitivos: sus condiciones representacionales. In-formar y trans-formar no son procesos de mediación en el sentido de Latour; son simplemente elementos en un proceso general de construcción y uso de medios representacionales, cuya posibilidad misma viene dada por la complejidad interna de un sistema de símbolos, su inserción en contextos interpretativos y la puesta en juego de las capacidades metarrepresentacionales de los agentes cognitivos. La cultura de la visualidad que es incorporada en el contexto de la ciencia es aquella que decide investigar sistemáticamente las condiciones de posibilidad de la representación y, con ello, evaluar las prácticas de representación de la naturaleza. 
En este aspecto se manifiesta una nueva línea de conexión transversal con el arte; la cultura moderna ha hecho explícito a través del desarrollo progresivo las técnicas de representación (la contribución de la perspectiva fue, de nuevo, paradigmática), la estructura misma del representar. Este hecho explica el cambio sufrido por las prácticas de producción y transmisión del saber que se identifican con la ruptura epistemológica (científica) de la Modernidad. Estas“ prácticas que permiten hacer explícito el mecanismo de la representación exhiben una mejor comprensión de la recogida y codificación de la información $\mathrm{y}$, también, de su transformación. En este proceso, el diseño de medios representacionales se convierte en decisivo. La hipótesis de este trabajo es que este diseño sólo es posible cuando la cultura domina las técnicas que permiten hacer explícita la capacidad metarrepresentacional de los sujetos cognitivos.

Aquí se encuentra la verdad de las tesis de Foucault, al comienzo de su magnífica obra Les mots et les choses. La garantía universal del acceso a la verdadera realidad se da en el terreno de la representación. Eso constituye la episteme clásica de la modernidad: todo ser es ser en la reprsentación, bajo la cual todo el saber se da en cuanto orden (mathesis) de los seres. El representar, autoconsciente, lograba aunar las líneas de fuga de la transformación histórica de la modernidad; el sujeto podía volverse sobre sí mismo, toparse con sus representaciones y controlarlas metódicamente mediante los procesos de análisis y orden. Esta constitución moderna del saber en torno a la categoría de representación se expresa paradigmáticamente en las transformaciones sufridas por el concepto de signo. Aún está por pensar la base material de sus conceptos fundamentales: especificar cómo las capacidades cognitivas metarrepresentacionales se hacen explícitas, sensibles, en medios representacionales públicos es un primer paso en esta línea.

\section{Notas}

1 Agradezco los comentarios y sugerencias de Diego Lawler y Francisco Javier Gil. Buena parte de las ideas de este artículo han sido el resultado de discusiones continuadas con Fernando Broncano. Tengo que recordar igualmente a mis alumnos de los Cursos de Doctorado impartidos en los dos últimos años en la Facultad de Filosofía de la Universidad de Salamanca, quienes forzaron las objeciones y me obligaron a perfeccionar mis argumentos.

2 En el fondo creo que es anecdótico el hecho de que los científicos sean «ignorantes» de literatura o que los literatos "desprecien» la ciencia. Estos son síntomas o bien 


\section{Cultura científica, cultura visual...}

de una simple división el trabajo (no todo el mundo puede hacer todo) o bien d una insensibilidad personal provocada por convicciones arraigadas sobre el valor de unos y otros. Y este es el problema básico, por supuesto.

3 Según la idea de W. Sellars, expuesta en su ensayo «La filosofía y la imagen científica del hombre", Ciencia, percepción y realidad, Tecnos, Madrid, 1971, 9-49. En esta obra, se encuentran reflexiones de más valor en torno a la defensa de la «imagen científica" del mundo que en buena parte de los escritos de debate sobre la escisión de las «dos culturas».

4 Esto ha sido desarrollado por Kemp en varias obras: Kemp. M., The Science of Art, Yale University, New Haven, 1990; o Visualizations. The Nature Book of Art and Science, Oxford University Press, Oxford, 2000. Lo que habría que evitar son extremismos (el punto común nace de una extirpación de la epistemología y la estética) como el expresado en la siguiente cita: «era mucho más difícil extirpar el pasado epistemológico de la actividad científica que liberar a la historia del arte de la estético, pero una vez que se completaron ambos movimientos, se abrió un vasto campo común y, en años recientes, una agitación de estudios ha "vascularizado" la conexión entre la visualización en la ciencia y las artes visuales» (Latour, B., "How to Be Iconophilic in Art, Science, and Religion", en Jones, C. A. y Galison, P. (eds.), Picturing Science. Producing Art, Routledge, New York, 1995, p. 422).

5 Así se han encargado de establecerlo convenientemente filósofos como G. Holton o A. I Miller.: Holton, G., "La imaginación en la ciencia", en Einstein, historia y otras pasiones. La rebelión contra la ciencia en el final del siglo XX, Taurus, Madrid, 1998, 111-141 (la cita del texto de Einstein procede de esta obra). Miller, A. I., "Aesthetics, Representation and Creativity in Art and Science», Leonardo, 28 (1995), 185-192; Miller, A. I., Insights of Genius. Imagery and Creativity in Science and Art, The MIT Press, Cambridge (Mass.), 2000. Para una presentación de interés en el caso de la técnica, donde el pensamiento visual adopta sus particulares formas, véase el ya clásico libro de Ferguson, Engineering and the Mind's Eye, The MIT Press, Cambridge, 1993.

6 Este era el sentido más genuino del concepto de «contexto de justificación» en Reichenbach, H., Experience and Prediction, The University of Chicago Press, Chicago, 1938.

7 Miller, en su libro Insights of Genius, aboga por la defensa de que la visualidad en la ciencia (y el arte) contribuye a desentrañar profundas estructuras del universo. Para ello recoge la historia de la estructura del átomo y el desarrollo de la mecánica cuántica durante los primeros 60 años del siglo XX, en un ejercicio complejo de historia 'e la ciencia, historia del arte y reflexión filosófica.

8 El interesante libro de Robin, H., The Scientific Image. From Cave to nputer (Freeman \& Co. Publ., New York, 1993) recoge imágenes de la historia ia ciencia según su contribución "racional» y metodológica a la comprensión de los fenómenos.

9 Sobre el tema de lo «irrepresentable», la contribución de Elkins, The domain of images (Cornell University Press, Ithaca y Londres, 1999) es fundamental.

10 En estos "lenguajes" (o mejor, medios representacionales), lo "natural» del signo no se manifiesta en cuanto semejanza sino en cuanto capacidades naturales de reconocimiento, que son aprovechadas "convencionalmente» para cumplir la función representacional.

11 Véase Kemp, M., Visualizations. The Nature Book of Art and Science, Oxford University Press, Oxford, 2000. 
12 Sobre esta distinción se puede consultar Miller, A. I., Insights of Genius. Imagery and Creativity in Science and Art, The MIT Press, Cambridge (Mass.), 2000 (original de 1996).

13 Panofsky, E., La perspectiva como forma simbólica, Tusquets, Barcelona, 1973, p. 40.

14 Ibid. 47.

15 Esta era la idea que animaba la magna obra, imprescindible igualmente, de E. Cassirer, La filosofía de la formas simbólicas, publicada entre 1923 y 1929. «La crítica de la razón se convierte así en crítica de la cultura. Trata de comprender y mostrar cómo todo contenido de la cultura, en la medida en que sea algo más que mero contenido aislado, en la medida en que esté fundado en un principio formal universal, presupone un acto originario del espíritu" (ed. cast., F.C.E., México, 1971, tm.I, p. 20). En lo que sigue voy a dar la vuelta a la interpretación de Cassirer de las formas para sacarlas de su versión idealista, claramente confesada en la obra, y convertirlas a un sano materialismo cultural. Por tanto, la presencia del término «espiritual» en mi texto no es más que concesión a la exposición de Cassirer; no tiene pretensión enfática.

16 Cassirer, E., Filosofía de las formas simbólicas, tm. I, p. 26-27.

17 Estas tesis han sido magníficamente expuesta por Edgerton, S. Y., The Heritage of Giotto's Geometry. Art and Science on the Eve of the Scientific Revolution, Cornell University Press, Ithaca, London, 1991. Para una crítica interesante de previas presentaciones de estas ideas, véase Mahoney, M. S., «Diagrams and Dynamics: Mathematical Perspectives on Edgerton's Thesis» en J. Shirley y F. Hoeniger (eds.), Science and the Arts in the Renaissance, Folger Library, Washington, 1985.

18 Esta es la expresión de Ivins, W. M., On the rationalization of sight, Plenum Pres, New York, 1973.

19 Edgerton, S. Y., "The Renaissance artist as a quantifier», en Hagen, M. A. (ed.), The Perception of Pictures, vol, I, Academic Press, New York, p. 189. Véase también su obra The Renaissance Discovery of Linear Perspective, Harper and Row, New York, 1976.

20 Latour, B., «Visualización y cognición: pensando con los ojos y con las manos», La balsa de la medusa, 45-6 (1998), p. 82.

21 «Hay dos maneras posibles de ignorar los procesos de visualización que nos interesan; uno es otorgar a la mente científica lo que debería otorgarse a las manos, a los ojos y los signos; la otra es centrarse exclusivamente en los signos qua signos, sin entrar a considerar la movilización de la que no son más que el frente" (Latour, B., "Visualización y cognición: pensando con los ojos y con las manos", La balsa de la medusa, 45-6 (1998), p. 114).

22 No voy a sacar punta a las metáforas de Latour, pero su comparación de estos móviles inmutables con los ángeles no deja de ser reveladora de su actitud más general. ¿Qué podríamos esperar de una posición que normativamente (dígase ética y políticamente) promocionara un mundo habitado por ángeles y los híbridos de la ciencia? «For my part, a civilization where we can have angels and immutable mobiles circulating, each in their own way, seems a much better place to live than the one in which science is supposed to access the World directly" (véase "How to Be Iconophilic in Art, Science, and Religion?», p. 438).

23 Latour, B., «Visualización y cognición: Pensando con los ojos y con las manos», p. 86.

24 «La información nunca es simplemente transferida, siempre es radicalmente transformada de un medio al siguiente» (Latour, B., «How to Be Iconophilic in Art, 


\section{Cultura científica, cultura visual...}

Science, and Religion?», en op. cit., p. 423). Me gustaría saber en qué consitiría esta transformación radical de la información y por qué hay que suponer que existe de hecho. Supongamos que tenemos una serie de datos de posición de un barco especificados a través de coordenadas y que somos capaces de "trasladarlos» a un mapa. Sin duda, la información se ha mantenido, en la medida en que soy capaz de interpretar ambos medios. Si lo que quiere decir es que se cambia de vehículo, esto es trivial, tan trivial que podría cambiarse de vehículo para la información sin que cambiara el medio en que se codifica la información. Pero si pretende defender -más coherentementeque el medio transforma la información en cuanto tal porque se presenta bajo un "código" visual y no numérico, sería difícil explicar después cómo podríamos resolver el mismo tipo de tareas apelando a la información recogida en ambos medios. Esto no quiere decir que cada medio no tenga su propia capacidad expresiva y su propia manera de organizar cognitivamente una tarea, pero de ello no se sigue que la información codificada sea necesariamente diferente en cuanto que se mantiene la coherencia transformacional entre medios. Sobre el tema volveré brevemente en una sección posterior.

25 Lo prefiero a "re-representaciones», término más confuso. Latour y otros asumen que en el proceso secuencial de intermediarios que se suceden con cada transformación se produce una representación de una representación. Después pondré en duda tal supuesto.

26 Considérense afirmaciones como las siguientes. «[La] repetición exacta de enunciados pictóricos ha tenido efectos incalculables sobre el conocimiento y el pensamiento, sobre la ciencia y la tecnología, de todo tipo» (Ivins, W. M., Prints and Visual Communication, The MIT Press, Cambridge (Mass.),1969, p. 3); «sin grabados habríamos tenido muy pocas de nuestras ciencias modernas, tecnologías, arqueologías o etnologías, pues todas ellas son dependientes ante todo de información transportada por medio de enunciados pictóricos o visuales exactamente repetibles» (Ibid. p. 3). "Propongo que esta creciente actitud europea de simpatía hacia la ciencia y las artes mecánicas fue tanto incitada como animada por la ilustracción de los libros impresos del siglo XVI" (Edgerton, S. Y., "The Renaissance Development of the Scientific Illustrarion", en J. Shirley y F. Hoeniger (eds.), Science and the Arts in the Renaissance, Folger Library, Washington, 1985, p. 194).

27 Plinio, Historia Natural, Cap. 4, libro 25.

28 Citado en Ivins, W. N., op. cit., p. 34-36.

29 Un elemento más que habría que resaltar es que este registro fiel no es imitación. El cambio de concepción del arte desde la mimesis a la creación se produce en este mismo momento.

30 La historia más detallada en Edgerton, S. Y., The Heritage of Giotto's Geometry, Cornell University Press, Ithaca, London, 1991.

31 Galluzzi, P., Les ingénieurs de la Renaissance de Brunelleschi à Léonard de Vinci, Cité des Sciences et de l'Industrie, Paris, 1995.

32 T. S. Kuhn, «La tradición matemática y la tradición experimental en el desarrollo de la física", La tensión esencial, F.C.E., México, 1982, p. 63.

33 Ibid. 69.

34 Kuhn distingue dos tradiciones también en el tratamiento de las artes mecánicas (y las no-mecánicas) en los finales del siglo XVI y durante el siglo XVII, unas más conectadas con las matemáticas y los tratados antiguos, y otras más ligadas a las necesidades utilitarias. 
35 Alpers, S., El arte de describir. El arte holandés en el siglo XVII, Hermann Blume, Madrid, 1987, p. 118.

36 Hooke, R., Micrografía, Círculo de Lectores, Madrid, 1996, p. 73.

37 Para algunas manifestaciones (no todas ellas igualmente aceptables) en esta línea, véase Hacking, I., "The Self-Vindication of the Laboratory Sciences", en Pickering, A. (ed.), Science as Practice and Culture, The University of Chicago Press, Chicago, 1992; o Pickering, A., The Mangle of Practice. Time, Agency and Science, The Chicago University Press, Chicago, 1995; o Galison, P., Image and Logic. A material culture of microphysics, The University of Chicago Press, Chicago, 1997.

38 Lo tomo de D. Sperber, La contagion des idées. Une théorie naturaliste de la culture, Odile Jacob, Paris, 1996.

39 La noción de contexto cognitivo no puedo desarrollarla aquí con detenimiento y tampoco puedo examinar las condiciones en que un contexto cognitivo se convierte en un contexto epistémico con criterios y controles de calidad estrictos. Este tema ha sido desarrollado por La cultura cognitiva de la ciencia. Condiciones de constitución del conocimiento socialmente distribuido, manuscrito.

40 Estas dificultades son de enorme importancia a la hora de desarrollar una teoría coherente y explicativamente relevante de las prácticas. Entre los críticos más perspicaces de la teoría de las prácticas está S. Turner, The Social Theory of Practices, The Chicago University Press, Chicago, 1994.

41 Este es uno de los aspectos en los que ha insistido la sociología del conocimiento científico para el caso de las representaciones igualmente.

42 Una caracterización de las condiciones de diseño y uso de medios representacionales, véase Vega, J. «Medios representacionales públicos», en Sagüillo, J. M., Falguera, J. L., Martínez, C. (eds.), Teorías formales y teorías empíricas. Aspectos fundacionales, ontosemánticos y pragmáticos, Universidade de Santiago de Compostela, Santiago de Compostela, 2001, 339-352.

43 Una buena caracterización de todos estos aspectos se puede encontrar en H. J. M. Tabachneck-Schijf y H. A. Simon, "Alternative representations of instructional material», en Peterson, D. (ed.), Forms of representation, Intelect Books, Exeter, 1996, 28-46, y en E. Hutchins, Cognition in the Wild, The MIT Press, Cambridge (Mass.), 1995.

44 Para un desarrollo más amplio, consúltese Broncano, F., La cultura cognitiva de la ciencia. Condiciones de constitución del conocimiento socialmente distribuido, manuscrito, y Recanati, F., Oratio obliqua, oratio recta. An essay on metarepresentation, The MIT Press, Cambridge (Mass.), 2000. También es útil la compilación de Sperber, D. (ed.), Metarepresenations. A multidisciplinary perspective, Oxford University Press, Oxford, 2000.

45 Broncano, F., La cultura cognitiva de la ciencia. Condiciones de constitución del conocimiento socialmente distribuido, manuscrito.

46 Panofsky, E., op. cit., p. 51. Para una extensión de la paradoja, véase E. Fox Keller, "The Paradox of Subjectivity», en Megill, A. (ed.), Rethinking Objectivity, Duke University Press, Durham, 1994. 